\title{
An in vitro evaluation of the anthelmintic activity of Hedychium spichatum rhizomes and Zingiber zerumbet rhizomes on the Pheritima Posthuma model: A comparative study
}

\author{
Shambaditya Goswami, Awanish Pandey, Poonam Tripathi, Asheesh Singh, Amrita Rai \\ Department of Pharmacy, Institute of Technology and Management, Gorakhpur, India \\ Submitted: 30-09-2010 \\ Revised: $11-11-2010$ \\ Published: 08-06-2011
}

A B S T R A C T

Ethanolic extracts of Hedychium spichatum rhizomes and Zingiber zerumbet rhizomes were taken for in vitro comparative studies on the anthelmintic activity against Pheritima posthuma. Different concentrations $(25,50,100 \mathrm{mg} / \mathrm{ml})$ of both the extracts were used for the activity. Varying albendazole concentrations $(25,50,100 \mathrm{mg} / \mathrm{ml})$ were used as a reference standard and normal saline $(0.9 \% \mathrm{NaCl})$ was used for the control treatment. The results were expressed in terms of time in minutes to report the paralysis and time of death of the earthworms. The results obtained from the study indicate toward the anthelmintic activity, supporting folk use of both the plants when compared with the standard. The results also established that $Z$. zerumbet was a more potent candidature of as compared with $H$. spichatum.

Key words: Albendazole, anthelmintic activity, Hedychium spichatum, Zingiber zerumbetw

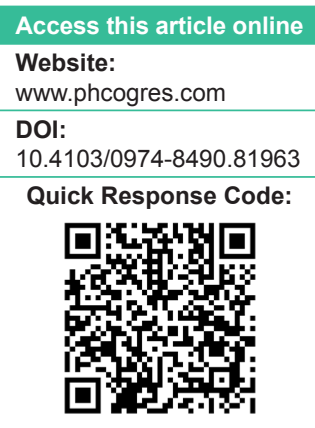

\section{INTRODUCTION}

From the ancient times, indigenous drugs have been used in the Indian medicinal system to treat different ailments and to provide therapeutic benefits. Our traditional system of medicine has made use of the different parts of plants in different types of diseases, including anthelmintic, antiinflammatory and antimicrobial activities. Kavirajes and Hakims are still using several medicinal plants to treat helminthiasis. During the recent years, medicinal chemistry has made great strides, especially in synthetic chemistry but, for the sake of therapeutic effect up to the level and nontoxic treatment for helminthiasis, the research of plantderived drug therapy is mostly needed. ${ }^{[1]}$

Rhizomes of Hedychium spichatum, commonly known as Gandhapalashi or Kapur-kachari, belong to the

\section{Address for correspondence:}

Mr. Shambaditya Goswami, Department of Pharmacy,

Institute of Technology and Management, Faculty Residence,

Block-C, AL-, SEC-7, GIDA, Gorakhpur, India.

E-mail: shambampharma@gmail.com
Zingiberaceae family, and have been reported for their folklore use in treating inflammatory and hyperglycemic conditions. ${ }^{[1]}$ The plant has also been evaluated for its cytotoxic activity by Reddy et al. ${ }^{[2]}$ The survey published by Akhtar et al. reported the use of $H$. spichatum as an anthelmintic in the Indian-Pakistan region. ${ }^{[3-4]}$

Zingiber zerumbet, commonly known as Narkachur and Banadrak, also belongs to the Zingiberaceae family. Rhizomes of $Z$. zerumbethave been reported for antipyretic and analgesic activities. ${ }^{[5]}$ Somchit et al. demonstrated the anti-inflammatory property of the ethanolic and aqueous extracts of $Z$. zerumbet. ${ }^{[6]}$ Nadia $e t$ al. also reported that Zerumbone isolated from $Z$. zerumbet inhibited cancer cell growth of human ovarian and cervical origin. ${ }^{[7]}$ However, Iqbal et al, performed a study on other plants of the Zingiberaceae and Cucurbutaceae families (Zingiber officinale, Curcurbita mexicana) in different anthelmintic models, ${ }^{[8]}$ but $H$. spichatum and $Z$. zerumbet have not been evaluated scientifically for anthelmintic activity. In light of the above facts, this study has been designed to evaluate $H$. spichatum and $Z$. zerumbet for their anthelmintic activity against a Pheritima posthuma model. 


\section{MATERIALS AND METHODS}

\section{Collection of plants}

The plant H. spichatum (specimen no. 97377) and Z. zerumbet rhizome (specimen no. 97769) were collected from the fields of Kusumha village (Kushinagar, Uttar Pradesh). The plant was authenticated by the National Botanical Research Institute (NBRI), Lucknow.

\section{Collection of earthworms}

Earthworms were collected from Tendua, Gorakhpur, and were identified and deposited in the Department of Pharmacy, ITM, GIDA, GKP, India.

\section{Preparation of the extracts}

Shade-dried small pieces of H. spichatum and shade-dried powder of the $Z$. zerumbet rhizomes were subjected to hot percolation by the Soxhlet apparatus using ethanol as a solvent.

\section{Procedure}

The anthelmintic activity was performed according to the method of Ghosh et al. (2005) on the adult Indian earthworm Pheritima posthuma. ${ }^{\left[{ }^{910]}\right.}$ Albendazole, the standard drug, was diluted with normal saline to obtain 25, 50 and $100 \mathrm{mg} / \mathrm{ml}$ concentrations and was poured into Petri dishes. Ethanolic extracts of both plants were diluted with normal saline to obtain 25,50 and $100 \mathrm{mg} / \mathrm{ml}$ concentrations. Normal saline $(0.9 \% \mathrm{NaCl})$ alone served as the negative control.

All these dilutions were poured into the Petri dishes accordingly. Six groups of earthworms $(n=6)$ were taken for the study. Earthworms, nearly equal sizes (about 8 $\mathrm{cm}$ ), were placed in each Petri dish at room temperature. Time for paralysis was noted down when no movement of any sort could be observed, except when the worms were shaken vigorously. Time of death for worms was recorded after ascertaining that the worms neither moved when shaken vigorously nor when dipped in warm water $\left(50^{\circ} \mathrm{C}\right)$. The paralysis time and lethal time were recorded in terms of minutes.

\section{RESULTS AND DISCUSSION}

In vitro anthelmintic activity was performed and the paralysis time and lethal time were recorded. Statistical evaluation of the data was performed by one-way ANOVA. The results were expressed as mean \pm SD using Graph Pad Instat $3(n=6)$.

The results show that for the $25 \mathrm{mg} / \mathrm{ml}$ concentration, albendazole showed the best activity for death time (124.83 $\pm 6.99 \mathrm{~min})$ and the ethanolic extract of $H$. spichatum and Z. zerumbet showed a death time of $146 \pm 2.828 \mathrm{~min}$ and $125.83 \pm 5.23 \mathrm{~min}$, respectively. Also, for the $50 \mathrm{mg} / \mathrm{ml}$ concentration, albendazole showed the highest activity against the worms $(95.5 \pm 4.84 \mathrm{~min})$ and the ethanolic extract of $H$. spichatum and $Z$. zerumbet showed a death time of $137.5 \pm 9.75 \mathrm{~min}$ and $112.33 \pm 5.87 \mathrm{~min}$, respectively. For the $100 \mathrm{mg} / \mathrm{ml}$ concentration, albendazole showed the least death time of $73.83 \pm 4.167 \mathrm{~min}$, and the ethanolic extract of $H$. spichatum and $Z$. zerumbet showed a death time of $96.66 \pm 3.266 \mathrm{~min}$ and $76.2 \pm 1.75 \mathrm{~min}$, respectively. The paralysis and death times of both the plants along with the standard is given in Table 1. The study revealed that both the plants' ethanolic extracts had significant activity at the higher concentration $(100 \mathrm{mg} / \mathrm{ml})$. Z. zerumbet has shown better activity than $H$. spichatum at a higher concentration $(100 \mathrm{mg} / \mathrm{ml})$ compared with the standard, albendazole $(100 \mathrm{mg} / \mathrm{ml})$. The comparison of the death time of both the plants in different concentrations with respect to the standard is given in Figure 1.

\section{CONCLUSION}

The present study enabled us to conclude the potential use of ethanolic extracts of both H. spichatum and Z. zerumbet as anthelmintic agents against Pheritima posthuma. Extensive research is needed to determine the individual component responsible for the anthelmintic activity and molecular mechanism responsible for the same.

\begin{tabular}{|c|c|c|c|}
\hline Treatment & Concentration & Paralysis time (min) & Death time (min) \\
\hline \multirow{3}{*}{ Albendazole (Std) } & $25 \mathrm{mg} / \mathrm{ml}$ & $55.66 \pm 4.59$ & $124.83 \pm 6.99$ \\
\hline & $50 \mathrm{mg} / \mathrm{ml}$ & $43.33 \pm 4.32$ & $95.5 \pm 4.84$ \\
\hline & $100 \mathrm{mg} / \mathrm{ml}$ & $34.66 \pm 3.327$ & $73.83 \pm 4.167$ \\
\hline \multirow[t]{3}{*}{ Hedychium spichatum (ethanolic extract) } & $25 \mathrm{mg} / \mathrm{ml}$ & $78.16 \pm 3.656$ & $146 \pm 2.828$ \\
\hline & $50 \mathrm{mg} / \mathrm{ml}$ & $62.33 \pm 4.131$ & $137.5 \pm 9.752$ \\
\hline & $100 \mathrm{mg} / \mathrm{ml}$ & $44 \pm 4.382$ & $96.66 \pm 3.266$ \\
\hline \multirow[t]{3}{*}{ Zingiber zerumbet (ethanolic extract) } & $25 \mathrm{mg} / \mathrm{ml}$ & $74.35 \pm 2.805$ & $125.83 \pm 5.23$ \\
\hline & $50 \mathrm{mg} / \mathrm{ml}$ & $51.34 \pm 1.24$ & $112.33 \pm 5.87$ \\
\hline & $100 \mathrm{mg} / \mathrm{ml}$ & $37.86 \pm 3.031$ & $76.2 \pm 1.75$ \\
\hline
\end{tabular}

\pm SD value, $n=6, P<0.01$ 


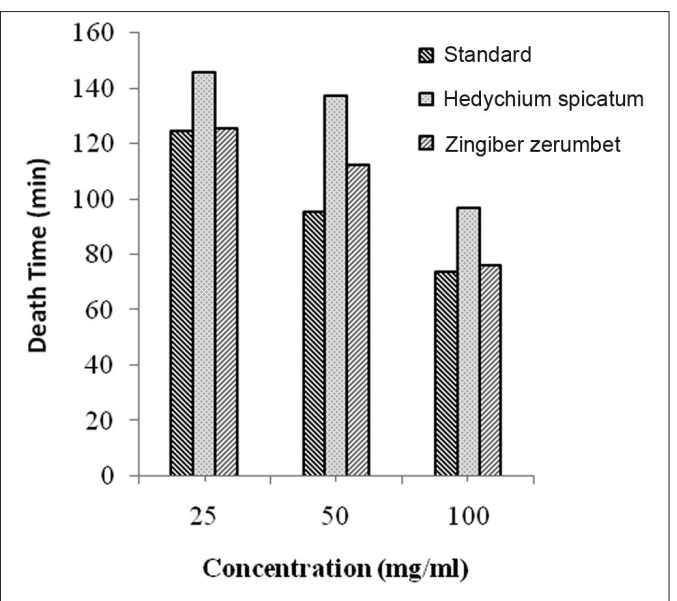

Figure 1: Comparative studies of death time of Hedychium spichatum and Zingiber zerumbet and the standard albendazole

\section{REFERENCES}

1. Chopra RN. The medical and economic aspect of Indian indigenous Drugs. p.6-7, 503, 510,675

2. Reddy PP, Rao RR, Shashidhar J, Sastry BS, Rao JM, Babu KS. Phyto-chemical investigation of labdane diterpenes from the rhizomes of Hedychium spicatum and their cytotoxic activity. Bioorg Med Chem Lett 2009;19:6078-81.

3. Akhtar M. Anthelmintic activity of medicinal plants with particular reference to their use in animals in the Indo-Pakistan subcontinent. Small Ruminant Res 2000;38:99-107.
4. Iqbal ZI, Jabbar A, Akhtar MS, Muhammad G, Lateef. Possible role of Ethnoveterinary medicine in poverty reduction in Pakistan: Use of botanical Anthelmintics as an example. J Agri Soc Sci 2005;1:187-95.

5. Somchit NM, Nur Shukriyah MH, Ahmad Bustamam A, Zuraini A. Anti-pyretic and analgesic activities of Zingiber zerumbet extracts. Int J Pharmacol 2005;1:277-80.

6. Somchit NM, Nur Shukriyah MH. Antiinflammatory property of Ethanolic and Aqueous extracts of Zingiber zerumbet. Indian J Pharmacol 2003;35:101-2.

7. Nadia Z, Zain M. Thesis Submitted to the School of Graduate Studies, Universiti Putra Malaysi in Fulfillment of the Requirements for the Degree of Master of Science, April 2005, Cytotoxic effects of zerumbone on ovarian and cervical cancer cell lines. http://psair.upm.edu.my/6318/

8. Iqbal Z, Nadeem QA, Khan MN, Akhtar MS, Nouman F In vitro anthelmintic activity of Allium sativum, Zingiber officinale, Curcurbita mexicana and Ficus religiosa. Int J Agr Biol 2001;3:454-7.

9. Ghosh T, Maity TK, Boseand A, Dash GK. Athelmintic activity of Bacopa monierr. Indian J Nat Prod 2005;21:16-9.

10. Rastogi T, Bhutda V, Moon K, Aswar PB, Khadabadi SS. Comparative studies on anthelmintic activity of Moringa oleifera and Vitex negundo. Asian J Res Chem 2009;2:181-2.

Cite this article as: Goswami S, Pandey A, Tripathi P, Singh A, Rai A. An in vitro evaluation of the anthelmintic activity of Hedychium spichatum rhizomes and Zingiber zerumbet rhizomes on the Pheritima Posthuma model: A comparative study. Phcog Res 2011;3:140-2.

Source of Support: Nil, Conflict of Interest: None declared. 